\title{
Analysis of Pre and Post-MCCG 2017: Leadership Effectiveness Through the Board Nomination Committee of Top 50 Malaysian PLCs
}

\author{
Dayana Mastura Baharudin \\ Department of Accounting \\ School of Management, Universiti Sains Malaysia, \\ Minden, 11800, Penang, Malaysia \\ Maran Marimuthu \\ Department of Management and Humanities, \\ Faculty of Science and Information Technology, \\ Universiti Teknologi PETRONAS, 32610, Seri Iskandar, Perak, Malaysia
}

Received: Aug. 24, 2020 Accepted: Sep. 17, 2020 Published: Sep. 18, 2020

doi:10.5296/bms.v11i2.17567 URL: https://doi.org/10.5296/bms.v11i2.17567

\begin{abstract}
Purpose - This paper investigates the impact of the two main aspects on selecting the right Board candidate including best practices within the position and structure along with the recruitment activities proposed under the Malaysian Corporate Governance Code (Code) compared across 2012 and 2017.

Design/ methodology approach - For this analysis, a target list of the top 50 PLCs based on market capitalization was gathered from 784 Malaysian PLCs as of 14 August 2020. In the annual review of the reports, this study includes statistical methods to quantify and interpret the disclosures.

Originality - This study reviews the developments of the policies from the Code in 2012 to the Code in 2017. Also applicable to other PLCs other than the top 50 Malaysian PLCs would be the Board Nomination Committee - Role and Structure and the Board Nomination Committee - Recruitment Activities scoring indices designed.
\end{abstract}


Keywords: board nomination committee, role, structure, recruitment, malaysian code of corporate governance, leadership, firm performance

\section{Introduction}

Corporate governance studies are often focused on the willingness to explore how boards operate and how their decisions can contribute to the creation of value (Filatotchev et al, 2009; Huse et al, 2011; 2015; Pirzada et al, 2016). The world had experienced the crash of East Asian economies in the second half of 1997. After this time, corporate governance was established in the private sector. Malaysia understands the importance of good governance and that is why Securities Commission Malaysia (SC) is committed to fostering and preserving a strong corporate governance culture. During the financial crisis in Southeast Asia of 1998, public confidence in Malaysia was badly impacted. Policymakers learned important lessons and, among others, focused on improving governance rules. The Securities Commission then launched numerous measures to strengthen the Malaysian Corporate Governance Structures (Malaysian Securities Commission, 2012). These included the issuance in March 2000 of the Malaysian Corporate Governance Code (Code) and was the landmark in the corporate governance reform in Malaysia. In the 2007 Code, the Board of Directors, audit committee and the internal audit function were subsequently revised, in order to clarify its functions and obligations. The 2012 Code acknowledged the role of directors as an active and accountable trustee, with a focus on enhancing the structure and composition of the directors. The Code are also responsible for ensuring that the company complies with laws and ethical principles and for maintaining an effective governance framework to ensure the proper management of risks and the level of internal controls, and for the development of a plan for controlling business behaviour (Securities Commission Malaysia, 2012).

\section{Problem Statement}

In Malaysia, among the efforts to create better governance among the business players in Malaysia were the introduction of the Code which emphasizes the establishment of legal regulation and stock market regulations and the creation of new authorities. The establishment of a nomination committee is one of the focus areas suggested by the Code in which the main function is to choose the company's future directors.

In the selection and appointment of the right board members, the appointing committee plays a crucial role, as it will then decide the board's composition. Despite the nominating committee's important position in the corporate governance system, it doesn't attract much interest among the academics. In the past, staff were selected for the board through personal connections, and the selection of people with the necessary skills and experience to develop and nurture was difficult for the board committee to deliberate on (Callahan et al, 2003).

Tarry (2009), states that the Nomination Committee can be considered running a "rubber stamp" exercise, which is a supported statement as both the CEO and the Chairman's recommendations would be taken into extreme consideration well and above the Nomination's Committee stringent approach. Now the Appointment Committee has made the selection of 
board members a more systematic and competent approach. It will now assess the business, execute the company plan, and obtain professional advice where appropriate (Callahan et al, 2003; Tarry 2009; Walker Review, 2009; Financial Reporting Council 2012; 2014). Furthermore, one of the least investigated areas of committee efficiency is its nomination committee (Huse 2011; Ruigrok et al., 2006).

The Nomination Committee now has a stronger and more independent role respected by the Chairman and CEO but the role is not of a popular topic among researchers to further investigate on.

Furthermore, the role has not been as thoroughly explored as, the Committee on Remuneration and Audit, despite the Appointment Committee is responsible for appointing board members and also senior roles such as the C-Suite Executives and the Chairman (Tarry 2009).

Accordance with the provisions to the 2017 Code, the Board Nominating Committee has a crucial function in which, whether the selection of candidates is based solely on suggestions made by current board members, administrators or major shareholders, the Nomination Committee may clarify why other sources have not been chosen, which is an absolute enhancement from 2012 Code for Corporate Malaysia.

In addition, five years on, the 2017 Code specified that, as Chair of the Nominating Committee, the Independent Director or the Senior Independent Director shall lead the career development and recruitment of Board Members, including the future Chairman and CEO, and shall conduct an annual Board Efficiency Review to ensure that the productivity of each individual Director is independently measured. This research has classified the Board Selection Committee into two focus areas, the first being the Function and Structure, and the second the Selection Activities. This study therefore seeks to examine the effect of the two focal areas within the Board Selection Committee on the firm financial results measured by the return on capital and the assets ratio.

\section{Research Objectives}

Research objective 1: To investigate the impact of the disclosure extent of the Board Nomination Committee - Role and Structure towards the financial performance of the top 50 Malaysian PLCs compared between the Code in 2012 and the Code in 2017.

Research objective 2: To investigate the impact of the disclosure extent of the Board Nomination Committee - Recruitment Activities towards the financial performance of the top 50 Malaysian PLCs compared between the Code in 2012 and the Code in 2017.

\section{Research Questions}

Research Question 1: Does the disclosure extent of the Board Nomination Committee Role and Structure compared between the Code in 2012 and the Code in 2017 have impact on the financial performance of the top 50 Malaysian PLCs?

Research Question 2: Does the disclosure extent of the Board Nomination Committee - 
Recruitment Activities compared between the Code in 2012 and the Code in 2017 have impact on the financial performance of the top 50 Malaysian PLCs?

\section{Literature Review}

\section{Independent Variable 1: Board Nomination Committee - Role and Structure}

The UK corporate governance codes and regulations have focused on helping the firm's management and board of directors make the best decisions in order to meet the interests of their stakeholders. It is the responsibility of the Nomination Subcommittee, which is part of the Board, to ensure that sufficient personnel, expertise, talent and experience have been chosen and named to assist the company in taking the right strategic choices (Financial Reporting Council 2012; 2014);

This implies that the Selection Committee plays an important role in the performance or failure of the organisation. The financial performance of the company depends in part on who has been appointed to the Board of Directors by the Selection Committee and who are the members of the executive Management Team. The Selection Committee must ensure that the best candidate with the right profile is selected to maximise the probability of success of the organisation.

\section{Independent Variable 2: Board Nomination Committee - Recruitment Activities}

Hambrick and Mason (1984) maintains that a diverse society benefits from strategic decisive intervention and greater innovation by multiple members of the board's collective capacity. Directors chosen with the appropriate skills, expertise and education are the responsibility of the Nomination Committee. When recruiting for the company, gender diversity should also be considered. In order to achieve the company's long-term goals, in which it must be ensured that any individual appointed to the Board complement and work together with the other Board members (Ruigrok et al., 2006).

The current governance structure of the United Kingdom recommends that this committee be composed of a plurality of independent directors on the board and that the Chief Executive not serve on that committee, while the President will serve on that committee for all matters not concerning the selection of a new Chairman.

Where a void exists on the Board of Directors, the Committee shall prepare a review of the role and qualifications expected of the new appointee, taking into account the combination of skills currently on the Board of Directors.

The Committee considers appointments from the company's stakeholders, such as investment firms, major shareholders, major lenders, existing directors and senior management, as well as recommendations from trained consultants and transparent recruitment. The process results in a shortlist of possible applicants sent to the committee.

The committee will then endorse the final recommendation and make an official nomination in the forthcoming general meeting for the shareholders' approval. In the end, the appointee 
receives a formal letter of nomination (Higgs report, 2003).

\section{Board Nomination Committee and Firm Performance}

Accounting and business performance were used as proxies to measure the dependent variables. The accounting performance variables for the three years from 2016 to 2018 of the companies listed in the Malaysian stock exchange have been computed from balance sheets and income statements. Asset returns and equity returns were used to calculate accounting efficiency.

Return on assets is an accounting performance measure that encapsulates the profits of businesses in the company (Yermack 1996; Beiner et al,2006). ROA is evaluating how a company can utilise its assets efficiently in income generation (Ross et al., (1998). The operating income is calculated as the share of the overall asset (Agyemang-Mintah, 2015).

Agyemang-Mintah (2015) found empirical findings indicating the existence of a Nomination Committee that have a beneficial impact on company performance as calculated by its Return on Assets by using the regression of the Ordinary Least Squares. The regression calculation for the Ordinary Least Squares and Random Effects also shows good and statistically relevant results.

This signifies that the Nominating Committee establishment by the board enhances the financial success of the company. The outcome means the Selection Committee was able to bring in the best workers to manage the company's affairs, resulting in a strong Return on Assets-

The empirical results of Agyemang-Mintah (2015) were consistent with earlier studies, such as findings of Callahan et al. (2003), Zajac and Westphal (1996) and Kaczmara etal. (2012), which noted a clear positive association with the company's success to the existence of a Nomination Committee. The empirical study also supports the statement that the company's involvement of the selection committee and the ROA as a measure of its profitability occurs in a positive relation.

Previous contrasting research by Azar, Sayyar, Zakaria \& Sulaiman (2018) on the Board Nomination Committee found that the ROA and ROE accounting-based efficiency metrics are highly insignificant in testing where there is a significant positive relationship between the size of the Nomination Committee and the firm performance. The findings are also similar when Tobin's $\mathrm{Q}$ is used as a metric to assess organizational success in this sense. The findings are also similar.

The findings of insignificance in calculating the relationship in both Board Selection Committee and the corporate performance of the Board research were conducted by Azar, Sayyar, Zakaria \& Sulaiman (2018) are due to the fact that from 2003 to 2012, there were 542 Bursa Malaysia PLCs selected from the total population of 900 but were not ranked according to either market capitalization to reflect prominence resulting in mixed results representing absolute insignificance. 


\section{Macrothink}

Generally, the top 30, top 50 or the top 100 Bursa Malaysia PLCs would have a better form of reporting within their annual reports which thoroughly reflects the reputation the PLCs when these PLCs are ranked accordingly, the outcome of the results of testing would be more congruent in line with being the crème de la crème in comparison to the lesser ranked PLCs.

\section{Theoretical Framework}

\section{Agency theory}

This relationship between the Board Nomination Committee - Role and Structure \& Recruitment Activities and the firm financial success is backed by the philosophy of the Agency theory.

The Agency Theory focuses, beforehand and primarily, on the division of ownership and control that takes place at the company level (Berle and Means, 1932) and on the interaction between the principal - agent relationship, which is fundamentally weak as well as several other problems within the organization (Berle and Means, 1932; Jensen and Meckling, 1976; Eisenhardt, 1989).

Initially, with asymmetry of information, where the agent is able to access information more easily within the firm than the principal; and, consequently, because of divergent interests, there are possible interest disagreement between the shareholder and the manager. (Jensen \& Meckling , 1976; Hill \& Jones, 1992).

The Agency's dilemma arises because the owner and the manager could have separate risk aversiveness behaviors about threat (Eisenhardt, 1989). In addition, there are different aims and interests across the principal and the agent (Eisenhardt, 1989).

It would be advisable if the principal were to create incentives for the officer to eliminate or exclude any selfish agent conduct in the light of the conflict of interests between the agent and the principal (Jensen and Meckling, 1976)

Instead of taking part in self-interest projects, the employee should behave to the best of interests of all stakeholders. The nomination committee that falls within the board should ensure that appropriate top management and board of directors are named to oversee and mitigate the agency's issues. 


\section{Conceptual Framework}

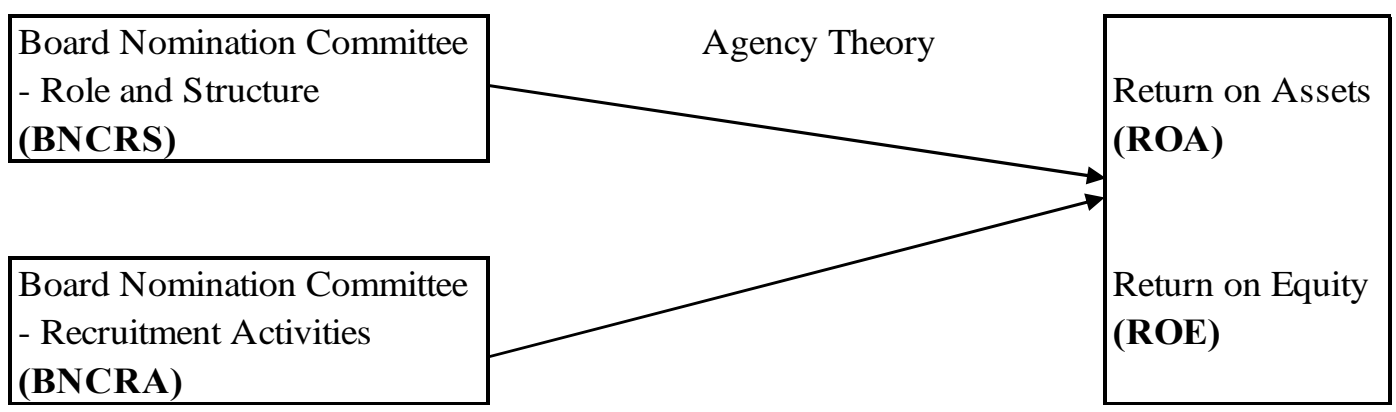

Controlled variables

Firm Age

Firm Size

Figure 1. Conceptual Framework - Board Nomination Committee

\section{Hypotheses of the study}

Hypothesis 1A: Board Nomination Committee - Role and Structure has impact on firm financial performance during the 2012 Code proxied by Return on Equity.

Hypothesis 1B: Board Nomination Committee - Role and Structure has impact on firm financial performance during the 2017 Code proxied by Return on Equity.

Hypothesis 1C: Board Nomination Committee - Role and Structure has impact on firm financial performance during the 2012 Code proxied by Return on Assets.

Hypothesis 1D: Board Nomination Committee - Role and Structure has impact on firm financial performance during the 2017 Code proxied by Return on Assets.

Hypothesis 2A: Board Nomination Committee - Recruitment Activities has impact on firm financial performance during the 2012 Code proxied by Return on Equity.

Hypothesis 2B: Board Nomination Committee - Recruitment Activities has impact on firm financial performance during the 2017 Code proxied by Return on Equity.

Hypothesis 2C: Board Nomination Committee - Recruitment Activities has impact on firm financial performance during the 2012 Code proxied by Return on Assets.

Hypothesis 2D: Board Nomination Committee - Recruitment Activities has impact on firm financial performance during the 2017 Code proxied by Return on Assets. 


\section{Macrothink

\section{Research model for empirical testing}

\section{Model 1:}

$\mathrm{ROE}=\beta_{0}+\beta_{1} \mathrm{BNCRS}+\beta_{2} \mathrm{BNCRA}+\beta_{3} \mathrm{AGE}+\beta_{4} \mathrm{SIZE}+$ cit

Whereas:

ROE $=$ Return on Equity to assess the financial performance of Malaysian Top 50 PLCs (external shareholder point of view)

ROA $=$ Return on assets for the assessment of the firm financial performance of the Top 50 Malaysian PLCs (internal leadership viewpoint)

BNCRS $=$ Board Nomination Committee - Role and Structure

BNCRA = Board Nomination Committee - Recruitment Activities

AGE $=$ Firm Age

SIZE $=$ Firm Size

$\boldsymbol{\varepsilon i t}=$ Error term

\section{Model 2:}

$\mathrm{ROA}=\beta_{0}+\beta_{1} \mathrm{BNCRS}+\beta_{2} \mathrm{BNCRA}+\beta_{3} \mathrm{AGE}+\beta_{4} \mathrm{SIZE}+\varepsilon \mathrm{it}$

\section{Context and Research Methods of Analysis of Variables and Their Operational Definitions}

A population of 784 Malaysian PLCs as at 14 August 2020 were used in this study in which a purposive sample of top 50 PLCs based on market capitalization were selected. This study offers descriptive statistics, regression analysis and content analysis in the assessment of the annual reports. Data collection for 3 years for this study will be for year 2016, 2017 and 2018 which will be explained further.

2016 was chosen as the 2012 Code is still effective and stable. The year 2017 has been chosen since the 2017 Code was released in 2017 and companies are in the process of updating their corporate governance processes from the 2012 Code to the 2017 Code and are most likely not yet enforcing the adopted amendments. Year 2018 was chosen to see the effect of the reform made in the 2017 and seeing that the new policy is likely to be gradually enforced. As a consequence, taking those 3 years would allow the researcher to distinguish between the 2017 Code's pre- and post-impacts. 


\section{Macrothink}

\section{Scoring indices}

\section{Board Nomination Committee - Role and Structure (6 items)}

- Chaired by an Independent Director

- Chaired by the Senior Independent Director

- The Chair of the Nomination Committee shall lead the succession planning

- The Chair of the Nomination Committee shall lead the appointment of Board Members

- The Chair of the Nomination Committee shall lead the appointment of the future Chairman

- The Chair of the Nomination Committee shall lead the appointment of the future Chief Executive Officer

\section{Board Nomination Committee - Recruitment Activities (4 items)}

- Selection of candidates as directors are solely based on recommendations made by existing board members, management or major shareholders

- Explain why other external sources are not used for selection of candidates as directors

- Sourcing director candidates from a director's registry and open advertisements or the use of independent search firms

- Disclosure in annual reports on how candidates for non-executive director positions were sourced

\section{Significance of Study}

The 2017 Code have enhanced and improved throughout the years of surviving the turbulence due to the financial crisis in Asia and globally. Therefore, the contents of the Board Nomination - Role and Structure which contained six items could be considered as highly rigorous for some PLCs which are not in the top 50 category but in the end, it is for the benefit of none other than the PLC itself and its stakeholders should they are able to attain all of the six criteria.

The Board Nomination Committee - Recruitment Activities includes four items of the criteria obtained from the 2017 Code which are also deemed very detailed as the PLCs should be able to disclose on the four types of recruitment activities to reflect good governance practiced. This scoring index describes the importance of the recruitment and selection of top executives with the rights qualities.

\section{Discussion and Directions for Future Research}

This research looks into the pre and post analysis of the 2017 Code taking into account on how the Board Nomination Committee operates during the era of MCCG 2012 compared to 
the era of MCCG 2017. Future research could look into the effects of the dual catastrophe in terms of the aftermath of the Covid-19 pandemic which has a profound impact on the economy as well. The Covid-19 pandemic which impacted all countries around the globe in terms of the health crisis and the economy crisis all combined into one resulted in business closing down and for the surviving businesses, future researchers may want to discover of a more in-depth and stronger role for the Board Nomination Committee or vice versa.

\section{References}

Agyemang-Mintah, P. (2015). The Nomination Committee and Firm Performance: An Empirical Investigation of UK Financial Institutions during the Pre/Post Financial Crisis. Corporate Board: Role, Duties \& Composition, 11(3), 2015. https://doi.org/10.22495/cbv11i3art14

Ashforth, B. E., \& Mael, F. (1989). Social identity theory and the organization. Academy of management Review, 14(1), 20-39. https://doi.org/10.5465/amr.1989.4278999

Azar, N., Sayyar, H., Zakaria, Z., \& Sulaiman, N. A. (2018). The Effects of Boards of Directors, Nomination Committees and Audit Committees on the Performance of Malaysian Listed Companies. International Journal of Economics and Management, 12(S1), 45-65.

Beiner, S., Drobetz, W., Markus, M., \& Zimmermann, H. (2006). An Integrated Framework of Corporate Governance and Firm Valuation. European Financial Management, 12(2), 249-283. https://doi.org/10.1111/j.1354-7798.2006.00318.x

Blau, P. M. (1977). Inequality and heterogeneity: A primitive theory of social structure, 7, Free Press New York.

Callahan, T. W., Millar, A. J., \& Schulman, C. (2003). An analysis of the effect of management participation in director selection on the long-term performance of the firm. Journal of Corporate Finance, 9, 169-181. https://doi.org/10.1016/S0929-1199(02)00004-4

Carpenter, M. A., \& Westphal, J. D. (2001). The strategic context of external network ties: Examining the impact of director appointments on board involvement in strategic decision making. Academy of Management Journal, 44(4), 639-660. https://doi.org/10.2307/3069408

Conyon, M. J., \& Peck, S. I. (1998). Board control, remuneration committees, and top management compensation. Academy of Management Journal, 41(2), 146-157. https://doi.org/10.2307/257099

Council, F. R. (2010). The UK corporate governance code. London: Financial Reporting Council.

Council, F. R. (2011). Guidance on board effectiveness. London: FRC.

Dedman, E., \& Lin, S. W. J. (2002). Shareholder wealth effects of CEO departures: Evidence from the UK. Journal of Corporate Finance, 8(1), 81-104. https://doi.org/10.1016/S0929-1199(01)00027-X 
Filatotchev, I., \& Boyd, B. K. (2009). Taking stock of corporate governance research while looking to the future. Corporate Governance: An International Review, 17(3), 257-265. https://doi.org/10.1111/j.1467-8683.2009.00748.x

Gay, K. (2001). A Boardroom Revolution? The impact of the Cadbury nexus on the work of non-executive directors of FTSE 350 companies. Corporate Governance: An International Review, 9(3), 152-164. https://doi.org/10.1111/1467-8683.00243

Harrison, D. A., \& Klein, K. J. (2007). What's the difference? Diversity constructs as separation, variety, or disparity in organizations. Academy of Management Review, 32(4), 1199-1228. https://doi.org/10.5465/amr.2007.26586096

Hillman, A. J., Cannella, A. A., \& Harris, I. C. (2002). Women and racial minorities in the boardroom: how do directors differ? Journal of management, 28(6), 747-763. https://doi.org/10.1177/014920630202800603

Hogg, M. A., \& Terry, D. I. (2000). Social identity and self-categorization processes in organizational contexts. Academy of management Review, 25(1), 121-140. https://doi.org/10.5465/amr.2000.2791606

Huse, M., Hoskisson, R., Zattoni, A., \& Viganò, R. (2011). New perspectives on board research: changing the research agenda. Journal of Management \& Governance, 15(1), 5-28. https://doi.org/10.1007/s10997-009-9122-9

Huse, M., Nielsen, S. T., \& Hagen, I. M. (2009). Women and employee-elected board members, and their contributions to board control tasks. Journal of Business Ethics, 89(4), 581-597. https://doi.org/10.1007/s10551-008-0018-4

Joshi, A., \& Roh, H. (2009). The role of context in work team diversity research: A meta-analytic review. Academy of Management Journal, 52(3), 599-627. https://doi.org/10.5465/amj.2009.41331491

Klein, A. (2002). Audit committee, board of director characteristics, and earnings management. Journal of accounting and economics, 33(3), 375-400. https://doi.org/10.1016/S0165-4101(02)00059-9

Lynall, M. D., Golden, B. R., \& Hillman, A. J. (2003). Board composition from adolescence to maturity: A multitheoretic view. Academy of management Review, 28(3), 416-431. https://doi.org/10.5465/amr.2003.10196743

McKnight, P. J., Milonas, N. T., Travlos, N. G., \& Weir, C. (2009). The Cadbury Code Reforms and Corporate Performance. IUP Journal of Corporate Governance, 8(1), 22-42.

Milliken, F. J., \& Martins, L. L. (1996). Searching for common threads: Understanding the multiple effects of diversity in organizational groups. Academy of management Review, 21(2), 402- 433. https://doi.org/10.5465/amr.1996.9605060217

Nielsen, S., \& Huse, M. (2010a). The contribution of women on boards of directors: Going 
beyond the surface. Corporate Governance: An International Review, 18(2), 136-148. https://doi.org/10.1111/j.1467-8683.2010.00784.x

Nielsen, S., \& Huse, M. (2010b). Women directors' contribution to board decision-making and strategic involvement: The role of equality perception. European Management Review, 7(1), 16-29. https://doi.org/10.1057/emr.2009.27

Ruigrok, W., Peck, S., Tacheva, S., Greve, P., \& Hu, Y. (2006). The Determinants and Effects of Board Nomination Committees. Journal of Management \& Governance, 10(2), 119-148. https://doi.org/10.1007/s10997-006-0001-3

Securities Commission Malaysia. (2012). Malaysian Corporate Code of Corporate Governance 2012.

Securities Commission Malaysia. (2017). Malaysian Corporate Code of Corporate Governance 2017

Stephenson, C. (2004). Leveraging diversity to maximum advantage: The business case for appointing more women to boards. Ivey Business Journal, 69(1), 1-5.

Vafeas, N. (1999). The nature of board nominating committees and their role in corporate governance. Journal of Business Finance \& Accounting, 26(1-2), 199-225. https://doi.org/10.1111/1468-5957.00253

Webber, S. S., \& Donahue, L. M. (2001). Impact of highly and less job-related diversity on work group cohesion and performance: A meta-analysis. Journal of Management, 27(2), 141-162. https://doi.org/10.1177/014920630102700202

Williams, K. Y., \& O'Reilly, C. A. (1998). Demography and diversity in organizations: A review of 40 years of research. Research in Organizational Behavior, 20, 77-140.

Yermack, D. (1996). Higher Market Valuation of Companies with a Small Board of Directors. Journal of Financial Economics, 40, 185-211. https://doi.org/10.1016/0304-405X(95)00844-5

Zagorchev, A., \& Gao, L. (2015) Corporate governance and performance of financial institutions, Journal of Economics and Business. https://doi.org/10.1016/j.jeconbus.2015.04.004

Zajac, E. J., \& Westphal, J. D. (1996), Director reputation, CEO /board power, and the dynamics of board interlocks. Administrative Science Quarterly, 41, 507-529. https://doi.org/10.2307/2393940

\section{Copyright}

Copyright for this article is retained by the author(s), with first publication rights granted to the journal.

This is an open-access article distributed under the terms and conditions of the Creative Commons Attribution license (http://creativecommons.org/licenses/by/4.0/). 